\title{
RAD51 Gene 135G/C polymorphism and the risk of four types of common cancers: a meta-analysis
}

Dan Cheng ${ }^{1,2}$, Huimin Shi ${ }^{1,2}$, Kan Zhang ${ }^{1,2}$, Lingling Yi ${ }^{1,2}$ and Guohua Zhen ${ }^{1,2^{*}}$

\begin{abstract}
Objectives: RAD51 gene plays an important role in the pathogenesis of squamous cell carcinoma of the head and neck (SCCHN), colorectal cancer, ovarian cancer and acute leukaemia. A number of studies assessed the association between RAD51 135G/C polymorphism and the risk of these cancers in different population. However, the results have been inconclusive. We performed a systematic meta-analysis to evaluate the association between RAD51 135G/C polymorphism and the risk of these four types of cancer.

Methods: Pubmed, Cochrane library and Chinese Biomedical Literature Database (CBM) were searched for case-control studies on RAD51 135G/C polymorphism and the risk of SCCHN, colorectal cancer, ovarian cancer and acute leukaemia published up to Oct 31, 2013. Odds ratios (ORs) with 95\% confidence intervals (Cls) were used to assess the strength of association.

Results: A total of twenty-two published studies, with 6836 cases and 8507 controls were included. Overall, no significant association was found between RAD51 135G/C polymorphism and the risk of the four types of cancers ( $\mathrm{G} / \mathrm{G}$ vs. $\mathrm{C} / \mathrm{C}: \mathrm{OR}=0.83,95 \% \mathrm{Cl}: 0.43-1.59, P=0.57$ ). However, there was a significant association between this polymorphism and SCCHN risk in the subgroup analysis by cancer type (G/G vs. C/C: OR=2.46, 95\% Cl: 1.08-5.61, $P=0.03)$.

Conclusion: The RAD51 135G/C polymorphism was associated with the risk of SCCHN.

Virtual slides: The virtual slide(s) for this article can be found here: http://www.diagnosticpathology.diagnomx.eu/ vs/1383180234106945.
\end{abstract}

Keywords: RAD51, Single nucleotide polymorphism, Cancer risk, Meta-analysis

\section{Introduction}

Cancer is one of the most common fatal diseases, which results from complex interactions between environmental and genetic factors [1]. More and more studies have focused on the role of gene polymorphism in the aetiology of cancers. Recently, there is growing evidence that single nucleotide polymorphism (SNP) plays an important role in carcinogenesis [2,3]. DNA repair systems have been considered to maintain genomic integrity by counting threats posed by DNA lesions. Deficiency in the DNA repair pathways might make these lesions unrepaired or repaired incorrectly, eventually leading to

\footnotetext{
* Correspondence: ghzhen@tjh.tjmu.edu.cn

'Department of Respiratory and Critical Care Medicine, Tongji Hospital, Tongji Medical College, Huazhong University of Science and Technology, Wuhan, Hubei, China

${ }^{2}$ Key Laboratory of Respiratory Diseases, Ministry of Health, Wuhan, Hubei, China
}

genome instability or mutations which may contribute directly to cancer.

RAD51 gene is located on chromosome 15q15.1 in humans [4]. The RAD51 protein encoding by RAD51 gene is essential for the repair of DNA damage. Growing evidences show that RAD51 has an irreplaceable role in the maintenance of genomic stability and the repair of DNA double-strand breaks [5]. The RAD51 genetic variations may contribute to the development of cancers [6]. A functional single nucleotide polymorphism, 135G/C (rs1801320), has been identified in the $5^{\prime}$ untranslated region of the RAD51 gene [7] and has been reported to affect gene transcription activity [8].

Up to now, a variety of molecular epidemiological studies have been conducted to estimate the association between the RAD51 135G/C polymorphism and risk of various cancers [9-17], including squamous cell carcinoma of the head 
and neck [18-21], colorectal cancer [22-25], ovarian cancer [26-28] and acute leukaemia [29-37]. However, the results of previous studies on the association between RAD51 135G/C polymorphism and cancer risk have been inconclusive, partially because of the relatively small sample size of most studies. Therefore, we carried out this metaanalysis to evaluate the association between RAD51 135G/ $\mathrm{C}$ polymorphism and risk of the four common types of cancers.

\section{Methods}

\section{Selection of eligible studies}

We conducted a comprehensive search in Pubmed, Cochrane library and Chinese Biomedical Literature Database (CBM), covering all articles published up to Oct 31, 2013, using the following terms: "RAD51" AND "polymorphism" AND "(squamous cell carcinoma of the head and neck) OR (colorectal cancer) OR (ovarian cancer) OR (acute leukaemia)". References of all identified studies and reviews were examined for additional articles.

\section{Study assessment}

Included studies in this meta-analysis met the following criteria: (a) a human case-control study on the association between RAD51 135G/C polymorphism and any of the four common cancers; (b) containing available genotype data in cases and controls for estimating an odds ratio (OR) and 95\% confidence interval $(\mathrm{CI})$; (c) genotype distributions of control population were consistent with Hardy-Weinberg equilibrium (HWE). The exclusion criteria were: (a) reviews, letters, editorial articles and case reports; (b) studies involving only a case population; (c) research not providing cancer information.

\section{Data extraction}

Two investigators (Cheng and Shi) extracted the data from all of the eligible publications according to the inclusion and exclusion criteria mentioned above. Primary extraction data were reviewed by Zhen, and any disagreement was resolved by discussion among the three authors. From each study, the following information was collected: first author's name, year of publication, study location, cancer type, sample size, source of control, the genotyping method, the number of genotype frequencies in cases and controls.

\section{Statistical analysis}

For each case-control study, we first examined whether the genotype frequencies in controls were consistent with HWE. ORs and 95\% CIs were calculated as a measure of the association between the RAD51 135G/C gene polymorphism and risk of the four cancers. The pooled ORs were performed for the homozygote comparison (G/G vs. C/C), heterozygote comparison $(\mathrm{G} / \mathrm{C}$ vs. $\mathrm{C} / \mathrm{C})$, dominant $(\mathrm{G} / \mathrm{G}+\mathrm{G} / \mathrm{C}$ vs. $\mathrm{C} / \mathrm{C})$ and recessive (G/G vs. $\mathrm{G} / \mathrm{C}+\mathrm{C} / \mathrm{C}$ ) genetic model comparison, and the significances of the summary ORs were determined by $Z$ test, $P<0.05$ was considered as statistically significant. The chi-square-based $Q$-test was used to assess the statistical heterogeneity among studies, and it was considered significant if $P<0.10$ [38]. If the $P$ value greater than 0.10 , indicating the absence of heterogeneity, then a fixedeffects model (the Mantel-Haenszel method) was applied to calculate the summary ORs [39]. Otherwise, the random-effects model (the DerSimonian and Laird method) was used [40]. $I^{2}$ was also calculated to test heterogeneity among included studies, with $I^{2}<25 \%, 25$ $75 \%$, and $>75 \%$ considered to represent low, moderate and high degree of heterogeneity, respectively [41]. Sensitivity analysis was performed to estimate the stability of the results, each study involved in this meta-analysis was deleted each time to reflect the influence of the individual data set to pooled ORs. Publication bias within the literature was assessed using Begg's test [42], an asymmetric funnel plot showed a potential publication bias. Egger's linear regression test $(P<0.05$ was considered significant publication bias) was also used to evaluate the symmetry of the funnel plot [43]. All of the analyses were carried out with RevMan 5.0.23 (Cochrane Library Software, Oxford, UK) and STATA11.0 (STATA Corporation, College Station, TX, USA).

\section{Results}

\section{Study characteristics}

A total of 133 related publications were identified, of which 19 studies were not accepted since they were not full articles (6 reviews, 7 meta-analysis, 4 comments, 2 case-reports). Fifty-nine articles were not about the above four cancers, 33 publications were excluded because they did not meet the inclusion criteria (11 not case-control studies, 6 not human studies, 7 not present the usable data, 7 not the gene loci, 2 not about polymorphism research). Finally, 22 studies including 6836 cases and 8507 controls were included in this metaanalysis (Figure 1).

The main characteristics of these 22 included studies are summarized in Table 1. There were 14 studies from European countries, 3 studies from Asian countries, 3 studies from American countries, 1 study from Australia and 1 study from Africa. In addition, 9 articles were population-based and 13 articles were hospital-based. The number of publications on SCCHN, colorectal, ovarian cancer and acute leukaemia were 4, 4, 5, and 9, respectively. The diagnosis of most of the cases was based on pathology. Healthy subjects matched for age and sex were used as controls. Polymerase chain reaction (PCR) or restriction fragment length polymorphism (RFLP) were performed as genotyping methods. The 
Finally, 22 case-control studies investigating

2 not about polymorphism research association between the $135 \mathrm{G} / \mathrm{C}$ polymorphism in RAD51 gene and risk of the four cancers were identified

Figure 1 Flow diagram of study selection.

Table 1 Characteristics of 22 published studies included in this meta-analysis

\begin{tabular}{|c|c|c|c|c|c|c|}
\hline First author & Year & Study location & Cancer type & Sample size & Source of controls & Genotyping methods \\
\hline 1. Lu JC & 2006 & USA & SCCHN & $716 / 719$ & $\mathrm{HCC}$ & PCR-RFLP \\
\hline 2. Gil J & 2011 & Poland & $\mathrm{CC}$ & $133 / 100$ & $\mathrm{HCC}$ & PCR-RFLP \\
\hline 3. Webb PM & 2005 & Australia & OC & $548 / 335$ & PCC & PCR \\
\hline 4. Gresner P & 2012 & Poland & SCCHN & $81 / 111$ & PCC & PCR \\
\hline 5. Seedhouse C & 2004 & UK & $\mathrm{AL}$ & $267 / 186$ & PCC & PCR \\
\hline 6. Jawad M & 2006 & UK & $\mathrm{AL}$ & $267 / 186$ & PCC & PCR \\
\hline 7. Krupa R & 2011 & Poland & $\mathrm{CC}$ & $100 / 100$ & $\mathrm{HCC}$ & $P C R$ \\
\hline 8. Sliwinski T & 2010 & Poland & SCCHN & $288 / 353$ & $\mathrm{HCC}$ & PCR-RFLP \\
\hline 9. Hamdy MS & 2011 & Egypt & $\mathrm{AL}$ & $50 / 30$ & $\mathrm{HCC}$ & PCR-RFLP \\
\hline 10. Liu L & 2011 & China & $\mathrm{AL}$ & $625 / 704$ & $\mathrm{HCC}$ & PCR \\
\hline 11. Romanowicz-MakowskaH & 2012 & Poland & $\mathrm{CC}$ & $320 / 320$ & $\mathrm{HCC}$ & PCR \\
\hline 12. WerbouckJ & 2008 & Belgium & SCCHN & $152 / 157$ & $\mathrm{HCC}$ & PCR \\
\hline 13. Romanowicz-MakowskaH & 2011 & Poland & OC & $120 / 120$ & $\mathrm{HCC}$ & PCR \\
\hline 14. Bhatla D & 2008 & USA & $A L$ & $452 / 646$ & PCC & $P C R$ \\
\hline 15. Voso MT & 2007 & Italy & $A L$ & $160 / 161$ & $\mathrm{HCC}$ & PCR-RFLP \\
\hline 16. Mucha B & 2012 & Poland & CC & $200 / 200$ & $\mathrm{HCC}$ & PCR-RFLP \\
\hline 17. Zhang ZQ & 2009 & China & $\mathrm{AL}$ & $166 / 458$ & $\mathrm{HCC}$ & PCR-RFLP \\
\hline 18. Auranen A (UK) & 2005 & UK & $\mathrm{OC}$ & $729 / 847$ & PCC & PCR \\
\hline 18. Auranen A (USA) & 2005 & USA & OC & $326 / 419$ & PCC & PCR \\
\hline 18. Auranen A (Danish) & 2005 & Denmark & $O C$ & 278/699 & PCC & PCR \\
\hline 21. Yang $L$ & 2011 & China & $\mathrm{AL}$ & $379 / 704$ & $\mathrm{HCC}$ & PCR \\
\hline 22. Rollinson S & 2006 & UK & $\mathrm{AL}$ & $479 / 952$ & PCC & PCR \\
\hline
\end{tabular}


genotype distributions and HWE examination results were shown in Table 2.

\section{Quantitative synthesis}

The evaluation of association between RAD51 135G/C gene polymorphism and the risk of the four types of cancers was summarized in Table 3. Overall, no significant association was found between RAD51 135G/C gene polymorphism and the risk of the four cancers $(\mathrm{G} /$ $\mathrm{G}$ vs. $\mathrm{C} / \mathrm{C}: \mathrm{OR}=0.83,95 \% \mathrm{CI}=0.43-1.59, P=0.57 ; \mathrm{G} / \mathrm{C}$ vs. $\mathrm{C} / \mathrm{C}: \mathrm{OR}=0.90,95 \% \mathrm{CI}=0.39-2.08, P=0.81 ; \mathrm{G} / \mathrm{G}+$ $\mathrm{G} / \mathrm{C}$ vs. $\mathrm{C} / \mathrm{C}: \mathrm{OR}=0.82,95 \% \mathrm{CI}=0.39-1.73, P=0.60 ; \mathrm{G} /$ G vs. $\mathrm{G} / \mathrm{C}+\mathrm{C} / \mathrm{C}: \mathrm{OR}=0.84,95 \% \mathrm{CI}=0.69-1.02, P=0.08)$. However, in the subgroup analysis by cancer type, there was a significant association between this polymorphism and SCCHN under homozygote comparison (G/G vs. C/ $\mathrm{C}: \mathrm{OR}=2.46,95 \% \mathrm{CI}=1.08-5.61 ; P=0.03$ ) (Figure 2). There was no significant association between this polymorphism and the risk of other three cancers under all comparisons. In the subgroup analyses by ethnicity or source of controls, no significant association was found in different genetic models.
Test of heterogeneity

For the comprehensive analysis, the $I^{2}$ showed a stable variation under all comparisons $(\mathrm{G} / \mathrm{G}$ vs. $\mathrm{C} / \mathrm{C}: P<$ $0.00001, I^{2}=81 \%$; G/C vs. C/C: $P<0.00001, I^{2}=89 \%$; G/ $\mathrm{G}+\mathrm{G} / \mathrm{C}$ vs. $\mathrm{C} / \mathrm{C}: P<0.00001, I^{2}=88 \% ; \mathrm{G} / \mathrm{G}$ vs. G/C + C/C: $P<0.00001, I^{2}=78 \%$ ). In the subgroup analyses of SCHNN and acute leukaemia, the $I^{2}$ showed a low or moderate variation under all comparisons. In the subgroup analyses of colorectal cancer and ovarian cancer, under most comparisons, the moderate heterogeneity was detected. For source of controls, there was no significant heterogeneity under all comparisons of populationbased case-control (PCC), except for heterozygous and dominant model comparisons (G/C vs. C/C: $P<0.00001$, $I^{2}=93 \% ; \mathrm{G} / \mathrm{G}+\mathrm{G} / \mathrm{C}$ vs. $\left.\mathrm{C} / \mathrm{C}: P<0.00001, I^{2}=92 \%\right)$ in hospital-based case-control (HCC). $P$ value for heterogeneity was not significant under all comparisons in the subgroup analyses of Asian population, but in Caucasian group, there were high degree heterogeneity under heterozygous and dominant model comparisons (G/C vs. C/C: $P<0.00001, I^{2}=90 \% ; \mathrm{G} / \mathrm{G}+\mathrm{G} / \mathrm{C}$ vs. $\mathrm{C} / \mathrm{C}: P<0.00001$, $\left.I^{2}=89 \%\right)$.

Table 2 Distribution of RAD51 genotype and allele among cancer patients and controls

\begin{tabular}{|c|c|c|c|c|c|c|c|c|c|c|c|c|}
\hline First author & Year & $\begin{array}{l}\text { Case } \\
\text { GG }\end{array}$ & GC & $\mathrm{CC}$ & $\begin{array}{l}\text { Control } \\
\text { GG }\end{array}$ & GC & $\mathrm{CC}$ & $\begin{array}{l}\text { Case } \\
\mathrm{G}\end{array}$ & $\mathrm{C}$ & $\begin{array}{l}\text { Control } \\
\text { G }\end{array}$ & $\mathrm{C}$ & HWE \\
\hline 1. Lu JC & 2006 & 624 & 91 & 1 & 622 & 96 & 1 & 1339 & 93 & 1340 & 98 & 0.17 \\
\hline 2. Gil J & 2011 & 100 & 29 & 4 & 73 & 27 & 0 & 229 & 37 & 173 & 27 & 0.19 \\
\hline 3. Webb PM & 2005 & 457 & 85 & 4 & 971 & 145 & 10 & 999 & 93 & 2087 & 165 & 0.08 \\
\hline 4. Gresner P & 2012 & 67 & 13 & 1 & 71 & 14 & 2 & 147 & 15 & 156 & 18 & 0.22 \\
\hline 5. Seedhouse C & 2004 & 210 & 44 & 3 & 166 & 18 & 2 & 464 & 50 & 350 & 22 & 0.08 \\
\hline 6. Jawad M & 2006 & 210 & 44 & 3 & 166 & 18 & 2 & 464 & 50 & 350 & 22 & 0.08 \\
\hline 7. Krupa R & 2011 & 61 & 36 & 3 & 36 & 35 & 29 & 158 & 42 & 107 & 93 & 0.003 \\
\hline 8. Sliwinski T & 2010 & 138 & 145 & 5 & 258 & 64 & 32 & 421 & 155 & 580 & 128 & 0.28 \\
\hline 9. Hamdy MS & 2011 & 39 & 9 & 2 & 26 & 3 & 1 & 87 & 13 & 55 & 5 & 0.06 \\
\hline 10. Liu L & 2011 & 72 & 25 & 8 & 511 & 175 & 18 & 169 & 25 & 1197 & 211 & 0.52 \\
\hline 11. Romanowicz- MakowskaH & 2012 & 51 & 56 & 213 & 91 & 164 & 65 & 158 & 482 & 346 & 294 & 0.57 \\
\hline 12. Werbouck J & 2008 & 136 & 15 & 1 & 134 & 23 & 0 & 287 & 17 & 291 & 23 & 0.32 \\
\hline 13. Romanowicz-MakowskaH & 2011 & 13 & 15 & 92 & 33 & 69 & 18 & 41 & 199 & 135 & 105 & 0.07 \\
\hline 14. Bhatla D & 2008 & 374 & 73 & 5 & 555 & 85 & 6 & 821 & 83 & 1195 & 97 & 0.18 \\
\hline 15. Voso MT & 2007 & 125 & 33 & 2 & 142 & 18 & 1 & 283 & 37 & 302 & 20 & 0.61 \\
\hline 16. Mucha B & 2012 & 161 & 34 & 5 & 157 & 37 & 6 & 356 & 44 & 351 & 49 & 0.05 \\
\hline 17. Zhang ZQ & 2009 & 117 & 47 & 2 & 315 & 123 & 20 & 281 & 51 & 753 & 163 & 0.08 \\
\hline 18. Auranen A (Danish) & 2005 & 241 & 36 & 1 & 616 & 78 & 5 & 518 & 38 & 1310 & 88 & 0.15 \\
\hline 18. Auranen A (UK) & 2005 & 642 & 84 & 3 & 745 & 100 & 2 & 1368 & 90 & 1590 & 104 & 0.48 \\
\hline 18. Auranen A (USA) & 2005 & 270 & 52 & 4 & 357 & 61 & 1 & 592 & 60 & 775 & 63 & 0.34 \\
\hline 21. Yang L & 2011 & 268 & 101 & 10 & 511 & 175 & 18 & 637 & 121 & 1197 & 211 & 0.52 \\
\hline 22. Rollinson S & 2006 & 431 & 34 & 1 & 817 & 115 & 4 & 896 & 36 & 1749 & 123 & 0.98 \\
\hline
\end{tabular}

HWE: $P$ value for Hardy-Weinberg equilibrium for RAD51 135G/C polymorphism among controls. 
Table 3 Total and stratified analysis of the RAD51 135G/C polymorphism on risk of the four cancers

\begin{tabular}{|c|c|c|c|c|c|c|c|c|c|c|c|c|c|c|}
\hline \multirow[t]{2}{*}{ Variables } & \multirow[t]{2}{*}{ No. $^{a}$} & \multirow[t]{2}{*}{ Case/Control } & \multicolumn{3}{|l|}{ GG vs. CC } & \multicolumn{3}{|l|}{ GC vs. CC } & \multicolumn{3}{|l|}{ GG+GC vs. CC } & \multicolumn{3}{|l|}{ GG vs. $\mathrm{GC}+\mathrm{CC}$} \\
\hline & & & $\mathrm{OR}(95 \% \mathrm{Cl})$ & $\mathrm{P}^{\mathrm{b}}$ & $\mathbf{P}$ & OR(95\% Cl) & $\mathrm{P}^{\mathrm{b}}$ & $\mathbf{P}$ & $\mathrm{OR}(95 \% \mathrm{Cl})$ & $\mathrm{P}^{\mathrm{b}}$ & $\mathbf{P}$ & OR(95\% Cl) & $\mathrm{P}^{\mathrm{b}}$ & $\mathbf{P}$ \\
\hline Total cancer types & 22 & $6836 / 8507$ & $0.83(0.43-1.59)$ & $0.00^{c}$ & 0.57 & $0.90(0.39-2.08)$ & $0.00^{c}$ & 0.81 & $0.82(0.39-1.73)$ & $0.00^{c}$ & 0.60 & $0.84(0.69-1.02)$ & $0.00^{c}$ & 0.08 \\
\hline $\mathrm{SCCHN}$ & 4 & $1237 / 1340$ & $2.46(1.08-5.61)$ & 0.50 & 0.03 & $2.20(0.30-16.22)$ & 0.02 & 0.44 & $2.50(0.76-8.28)$ & 0.25 & 0.13 & $0.84(0.40-1.75)$ & $0.00^{c}$ & 0.64 \\
\hline CC & 4 & $753 / 720$ & $0.92(0.08-10.55)$ & $0.00^{c}$ & 0.95 & $0.65(0.05-8.08)$ & $0.00^{c}$ & 0.74 & $0.79(0.06-10.16)$ & $0.00^{c}$ & 0.85 & $1.12(0.53-2.35)$ & $0.00^{c}$ & 0.77 \\
\hline OC & 5 & $2001 / 2420$ & $0.42(0.10-1.78)$ & 0.0007 & 0.24 & $0.41(0.06-2.67)$ & $0.00^{c}$ & 0.35 & $0.40(0.07-2.18)$ & $0.00^{c}$ & 0.29 & $0.80(0.62-1.03)$ & 0.07 & 0.09 \\
\hline AL & 9 & $2845 / 4027$ & $0.82(0.49-1.39)$ & 0.26 & 0.47 & $1.00(0.59-2.08)$ & 0.29 & 0.99 & $0.85(0.50-1.44)$ & 0.25 & 0.60 & $0.82(0.63-1.07)$ & 0.002 & 0.14 \\
\hline \multicolumn{15}{|l|}{ Source of controls } \\
\hline $\mathrm{HCC}$ & 13 & $3409 / 4126$ & $0.77(0.30-1.98)$ & $0.00^{c}$ & 0.58 & $0.79(0.24-2.60)$ & $0.00^{c}$ & 0.70 & $0.74(0.26-2.13)$ & $0.00^{c}$ & 0.58 & $0.82(0.60-1.12)$ & $0.00^{c}$ & 0.20 \\
\hline PCC & 9 & $3427 / 4381$ & $0.93(0.53-1.62)$ & 0.87 & 0.79 & $1.14(0.64-2.02)$ & 0.87 & 0.66 & $0.95(0.54-1.67)$ & 0.88 & 0.87 & $0.88(0.71-1.09)$ & 0.01 & 0.25 \\
\hline \multicolumn{15}{|l|}{ Ethnicity } \\
\hline Asian & 3 & 1170/1866 & $0.92(0.27-3.19)$ & 0.01 & 0.90 & $0.98(0.28-3.40)$ & 0.01 & 0.97 & $0.94(0.27-3.26)$ & 0.009 & 0.92 & $0.94(0.77-1.14)$ & 0.64 & 0.52 \\
\hline Caucasian & 18 & $5616 / 6611$ & $0.80(0.36-1.79)$ & $0.00^{c}$ & 0.59 & $0.86(0.31-2.38)$ & $0.00^{c}$ & 0.77 & $0.79(0.32-1.95)$ & $0.00^{c}$ & 0.61 & $0.83(0.65-1.05)$ & $0.00^{c}$ & 0.13 \\
\hline African & 1 & $50 / 30$ & $0.75(0.06-8.70)$ & & 0.82 & $1.50(0.10-23.07)$ & & 0.77 & $0.83(0.07-9.54)$ & & 0.88 & $0.55(0.16-1.90)$ & & 0.34 \\
\hline
\end{tabular}

${ }^{\text {aNumber of studies. }}$

${ }^{\mathrm{b}} \mathrm{P}$ value of Q-test for heterogeneity test.

cFixed-effects model was used when $\mathrm{P}$ value for heterogeneity test $<0.10$, otherwise, random-effects model was used.

SCCHN: squamous cell carcinoma of the head and neck; CC: colorectal cancer; OC: ovarian cancer; AL: acute leukaemia. 


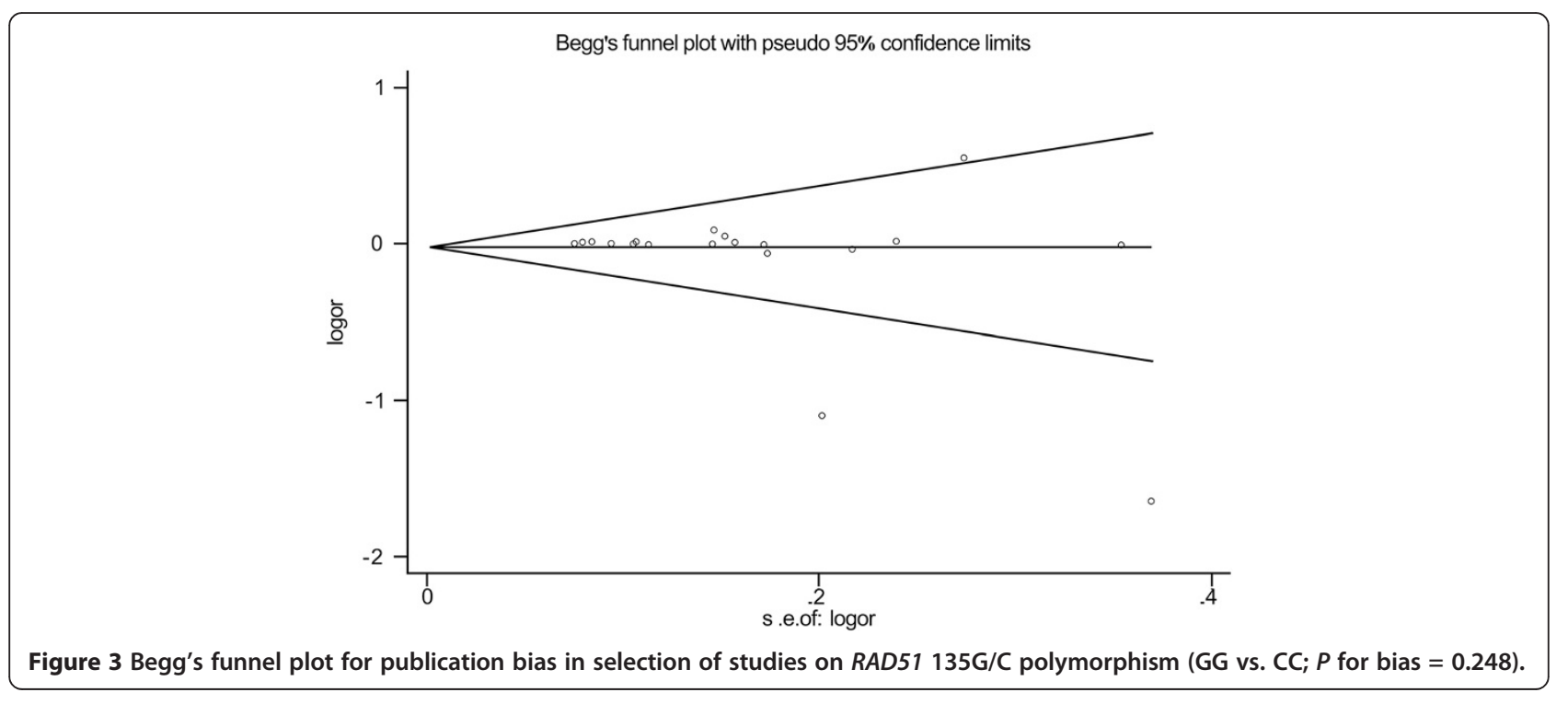




\section{Sensitivity analysis}

Sensitivity analyses were performed to assess the stability of the results in this meta-analysis. Statistically similar data were obtained after sequentially excluding each study, indicating that our results were statistically reliable.

\section{Publication bias}

Begg's funnel plot and Egger's test were used to assess the publication bias of included studies. Publication bias was not observed in Begg's funnel plot. The shape of the funnel plots showed to be symmetrical (G/G vs. C/C) and the Egger's test did not show any evidence of publication bias $(P=0.248$ for $\mathrm{G} / \mathrm{G}$ vs. $\mathrm{C} / \mathrm{C}$ ) (Figure 3 ). These data indicate that there is no significant publication bias in this meta-analysis.

\section{Discussion}

The RAD51 protein encoding by RAD51 gene is essential for the repair of DNA damage. A number of original studies have reported the association between RAD51 $135 \mathrm{G} / \mathrm{C}$ polymorphism and the risk of cancer with inconclusive results, These inconsistent results are possibly because of a small effect of the polymorphism on cancers risk or the relatively low statistical power of the published studies. To better understanding of this association, a meta-analysis, which potentially investigates a large number of individuals and could estimate the effect of a genetic factor on the risk of cancers, was needed to provid a quantitative approach for combining the results of various studies with the same topic, and for estimating and explaining their diversity $[44,45]$. We performed a meta-analysis including 6836 cases and 8507 controls from 22 case-control studies to evaluate the association between RAD51 135G/C polymorphism and risk of $\mathrm{SCCHN}$, colorectal cancer, ovarian cancer and acute leukaemia.

The overall population analysis showed no significant association between RAD51 135G/C polymorphism and risk of SCCHN, colorectal cancer, ovarian cancer and acute leukaemia in any genetic model. However, in the subgroup analysis by cancer type, we found that the $135 \mathrm{G} / \mathrm{C}$ polymorphism of the RAD51 gene was associated with a significantly increased SCCHN risk. There was an aggregated OR of 2.46 (95\% CI =1.08-5.61) for increased SCCHN susceptibility under homozygote comparison. This indicates that the RAD51 $135 \mathrm{G} / \mathrm{C}$ polymorphism may contribute to pathogenesis of SCCHN. GG genotype has been reported to enhance $R A D 51$ gene transcription activity [8], individuals with GG genotype may be more likely to develop SCCHN than those with CC or GC genotype. No associations were found between this polymorphism and the risk of colorectal cancer, ovarian cancer and acute leukaemia, which was consistent with previous reports [22,23,27-29,32,36].

Heterogeneity is one of the important issues in performing a meta-analysis. In the present meta-analysis, heterogeneity was found in almost all comparisons. Using random-effect models and the stratified analyses by cancer type, sources of control and ethnicity, the heterogeneity was significantly decreased in most of the comparisons. The sensitivity analysis did not alter the results of our meta-analysis, indicating the results are stable. Meanwhile, the publication bias for the association between $R A D 51$ $135 \mathrm{G} / \mathrm{C}$ polymorphism and the risk of the four types of cancers were not detected.

The present meta-analysis has some limitations. First, the control subjects were not uniformly defined. Selection bias and classification bias were possible because the included controls may have other different risks of developing cancers. Second, in the subgroup analyses, the sample sizes of Asian and African population were relatively small, not having enough statistical power to explore the real association. Third, cancer is a multi-factorial disease, our meta-analysis was based on unadjusted estimates.

In conclusion, the GG genotype of RAD51 135G/C was associated with a significantly increased risk of SCCHN. However, there was no significant association between this polymorphism and colorectal cancer, ovarian cancer or acute leukaemia susceptibility.

\section{Competing interest}

The authors have declared that no competing interests exist.

\section{Authors' contributions}

DC performed the literature search, data extraction, statistical analysis and drafted the manuscript. HS, KZ and LY participated in data extraction. GZ supervised the literature search, data extraction, statistical analysis and drafted the manuscript. All authors read and approved the final manuscript.

\section{Funding}

This study was supported by National Natural Science Foundation of China Grant 81170022, and National Key Technology R\&D Program of the 12th Five-year Development Plan 2012BAI05B01.

Received: 30 August 2013 Accepted: 27 December 2013 Published: 23 January 2014

\section{Reference}

1. Pharoah PD, Dunning AM, Ponder BA, Easton DF: Association studies for finding cancer-susceptibility genetic variants. Nat Rev Cancer 2004, 4:850-860.

2. Zeljic K, Supic G, Jovic N, Kozomara R, Brankovic-Magic M, Obrenovic M, et al: Association of TLR2, TLR3, TLR4 and CD14 genes polymorphism with oral cancer risk and survival. Oral Dis 2013. doi: 10.1111/odi.12144.

3. Vispé S, Cazaux C, Lesca C, Defais M: Overexpression of Rad51 protein stimulates homologous recombination and increases resistance of mammalian cells to ionizing radiation. Nucleic Acids Res 1998, 26:2859-2864

4. Shinohara A, Ogawa H, Matsuda Y, Ushio N, Ikeo K, Ogawa T: Cloning of human, mouse and fission yeast recombination genes homologous to RAD51 and recA. Nat Genet 1993, 4:239-243.

5. Baumann P, West SC: Role of the human RAD51 protein in homologous recombination and double-stranded break repair. Trends Biochem Sci 1998, 23:247-251.

6. Thacker J: The RAD51 gene family, genetic instability and cancer. Cancer Lett 2005, 219:125-135. 
7. Wang WW, Spurdle AB, Kolachana P, Bove B, Modan B, Ebbers SM, Suthers G, Tucker MA, Kaufman DJ, Doody MM, et al: A single nucleotide polymorphism in the 5 'untranslated region of RAD51 and risk of cancer among BRCA1/2 mutation carriers. Cancer Epidemiol Biomarkers Prev 2001 10:955-960

8. Hasselbach L, Haase S, Fischer D, Kolberg HC, Sturzbecher HW: Characterisation of the promoter region of the human DNA-repair gene Rad51. Eur J Gynaecol Oncol 2005, 26:589-598.

9. Shin A, Lee KM, Ahn B, Park CG, Noh SK, Park DY, Ahn SH, Yoo KY, Kang D: Genotype-phenotype relationship between DNA repair gene genetic polymorphism and DNA repair capacity. Asian Pac J Cancer Prev 2008, 9:501-505.

10. Smolarz B, Samulak D, Michalska M, Góralczyk B, Szyłło K, Lewy J, Sporny S, Kokołaszwili G, Burzyński M, Romanowicz-Makowska H: 135G >C and $172 \mathrm{G}>$ Tpolymorphism in the 5' untranslated region of RAD51 and sporadic endometrial cancer risk in Polish women. Pol J Pathol 2011, 62:157-162.

11. Dhillon VS, Yeoh E, Fenech M: DNA repair gene polymorphisms and prostate cancer risk in South Australia-results of a pilot study. Urologic Oncology: Seminars and Original Investigations 2011, 29:641-646.

12. Figueroa JD, Malats N, Rothman N, Real FX, Silverman D, Kogevinas M, et al: Evaluation of genetic variation in the double-strand break repair pathway and bladder cancer risk. Carcinogenesis 2007, 28:1788-93.

13. Pasaje CF, Kim JH, Park BL, Cheong HS, Bae JS, Park TJ, Lee JS, Kim Y, Lee HS, Koh I, et al: Lack of association of RAD51 genetic variations with hepatitis $B$ virus clearance and occurrence of hepatocellular carcinoma in a Korean population. J Med Virol 2011, 83:1892-1899.

14. Poplawski T, Arabski M, Kozirowska D, Blasinska-Morawiec M, Morawiec Z, Morawiec-Bajda A, Klupińska G, Jeziorski A, Chojnacki J, Blasiak J: DNA damage and repair in gastric cancer-A correlation with the hOGG1 and RAD51 genes. polymorphisms. Mutation Research/Fundamental and Molecular Mechanisms of Mutagenesis 2006, 601:83-91.

15. Fabiani E, D'Alò F, Scardocci A, Greco M, Di Ruscio A, Criscuolo M, Fianchi L, Pagano L, Hohaus S, Leone G, Voso Maria T: Polymorphisms of detoxification and DNA repair enzymes in myelodyplastic syndromes. Leuk Res 2009, 33:1068-1071.

16. Wang LE: Polymorphisms of DNA Repair Genes and Risk of Glioma. Cancer Res 2004, 64:5560-5563.

17. Romanowicz-Makowska H, Smolarz B, Gajęcka M, Kiwerska K, Rydzanicz M, Kaczmarczyk D, Olszewski J, Szyfter K, Błasiak J, Morawiec-Sztandera A: Polymorphism of the DNA repair genes RAD51 and XRCC2 in smoking- and drinking-related laryngeal cancer in a Polish population. Arch Med Sci 2012, 6:1065-1075

18. Gresner P, Gromadzinska J, Polanska K, Twardowska E, Jurewicz J, Wasowicz W: Geneticvariability of Xrcc3 and Rad51 modulates the risk of head and neck cancer. Gene 2012, 504:166-174.

19. Lu J, Wang LE, Xiong P, Sturgis EM, Spitz MR, Wei Q: 172G > T variant in the $5^{\prime}$ untranslated region of DNA repair gene RAD51 reduces risk of squamous cell carcinoma of the head and neck and interacts with a P53 codon 72 variant. Carcinogenesis 2006, 28:988-994.

20. Sliwinski T, Walczak A, Przybylowska K, Rusin P, Pietruszewska W

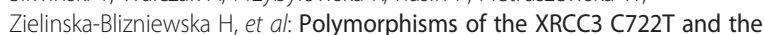
RAD51 G135C genes and the risk of head and neck cancer in a Polish population. Exp Mol Pathol 2010, 89:358-366.

21. Werbrouck J, De Ruyck K, Duprez F, Van Eijkeren M, Rietzschel E, Bekaert S, et al: Single-nucleotide polymorphisms in DNA double-strand break repair genes: Association with head and neck cancer and interaction with tobacco use and alcohol consumption. Mutat Res 2008, 656:74-81.

22. Mucha B, Przybyłowska-Sygut K, Dziki L, Dziki A, Sygut A, Majsterek I: Lack of association between the 135G/C RAD51 gene polymorphism and the risk of colorectal cancer among Polish population. Pol Przegl Chir 2012, 84:358-362.

23. Gil J, Ramsey D, Stembalska A, Karpinski P, Pesz KA, Laczmanska I, et al: The $\mathrm{C} / \mathrm{A}$ polymorphism in intron 11 of the XPC gene plays a crucial role in the modulation of an individual's susceptibility to sporadic colorectal cancer. Mol Biol Rep 2012, 39:527-534

24. Krupa R, Sliwinski T, Wisniewska-Jarosinska M, Chojnacki J, Wasylecka M, Dziki $L$, et al: Polymorphisms in RAD51, XRCC2 and XRCC3 genes of the homologous recombination repair in colorectal cancer-a case control study. Mol Biol Rep 2011, 38:2849-2854.
25. Romanowicz-Makowska H, Samulak D, Michalska M, Sporny S, Langner E, Dziki A, et al: RAD51 gene polymorphisms and sporadic colorectal cancer risk in Poland. Pol J Pathol 2012, 3:193-198.

26. Romanowicz-Makowska H, Smolarz B, Samulak D, Michalska M, Lewy J, Burzyński $M$, et al: A single nucleotide polymorphism in the $5^{\prime}$ untranslated region of RAD51 and ovarian cancer risk in Polish women. Eur J Gynaecol Oncol 2012, 33:406-410.

27. Auranen A, Song H, Waterfall C, DiCioccio RA, Kuschel B, Kjaer SK, et al: Polymorphisms in DNA repair genes and epithelial ovarian cancer risk. Int J Cancer 2005, 117:611-618.

28. Webb PM, Hopper JL, Newman B, Chen XQ, Kelemen L, Giles GG, et al: Double-strand break repair gene polymorphisms and risk of breast or ovarian cancer. Cancer Epidemiology Biomarker Prev 2005, 14:319-323.

29. Zhang ZQ, Yang L, Zhang Y, Yang YH, Nie L, Li L, et al: Relationship between NQ01C(609 T), RAD51(G135C), XRCC3(C241T) single nucleotide polymorphisms and acute lymphoblastic leukemia. Zhongguo Shi Yan Xue Ye Xue Za Zhi 2009, 17:523-528.

30. Hamdy MS, El-Haddad AM, Bahaa El-Din NM, Makhlouf MM, Abdel-Hamid SM: RAD51 and XRCC3 gene polymorphisms and the risk of developing acute myeloid leukemia. J Investig Med 2011, 59:1124-1130.

31. Liu L, Yang L, Mi YC, Li JY, Qin TJ, Xu ZF, et al: Relationship between RAD51-g135C and XRCC3-C241T polymorphisms and prognosis of inv $(16) / t(16 ; 16)$ (CBFbeta-MYH11) acute myeloid leukemia. Zhonghua Xue Ye Xue Za Zhi 2011, 32:433-438.

32. Bhatla D, Gerbing RB, Alonzo TA, Mehta PA, Deal K, Elliott J, et al: DNA repair polymorphisms and outcome of chemotherapy for acute myelogenous leukemia: a report from the children's oncology group. Leukemia 2007, 22:265-272

33. Jawad M, Seedhouse CH, Russell N, Plumb M: Polymorphisms in human homeobox HLX1 and DNA repair RAD51 genes increase the risk of therapy-related acute myeloid leukemia. Blood 2006, 108:3916-3918.

34. Liu L, Yang L, Mi Y, Wang J, Li J, Zhang Y, et al: RAD51 and XRCC3 polymorphisms: Impact on the risk and treatment outcomes of de novo inv(16) or $\mathrm{t}(16 ; 16) / \mathrm{CBF} \beta-\mathrm{MYH} 11(+)$ acute myeloid leukemia. Leuk Res 2011, 35:1020-1026.

35. Rollinson S, Smith AG, Allan JM, Adamson PJ, Scott K, Skibola CF, et al: RAD51 homologous recombination repair gene haplotypes and risk of acute myeloid leukaemia. Leuk Res 2007, 31:169-174.

36. Seedhouse C, Faukner R, Ashraf N, Das-Gupta E, Russell N: Polymorphisms in Genes Involved in Homologous Recombination Repair Interact to Increase the Risk of Developing Acute Myeloid Leukemia. Clinical Cancer Res 2004, 10:2675-2680.

37. Voso M, Fabiani E, D'Alo F, Guidi F, Di Ruscio A, Sica S, et al: Increased risk of acute myeloid leukaemia due to polymorphisms in detoxification and DNA repair enzymes. Ann Oncol 2007, 18:1523-1528.

38. Higgins JP, Thompson SG: Quantifying heterogeneity in a meta-analysis. Stat Med 2002, 21:1539-1558.

39. Mantel N, Haenszel W: Statistical aspects of the analysis of data from retrospective studies of disease. J Natl Cancer Inst 1959, 22:719-748.

40. DerSimonian R, Laird N: Meta-analysis in clinical trials. Control Clin Trials 1986, 7:12

41. Higgins JP, Thompson SG, Deeks JJ, Altman DG: Measuring inconsistency in meta-analyses. Br Med J 2003, 327:557-560.

42. Munafo MR, Clark TG, Flint J: Assessing publication bias in genetic association studies: evidence from a recent meta-analysis. Psychiatry Res 2004, 129:33-44.

43. Egger M, Davey Smith G, Schneider M, Minder C: Bias in meta-analysis detected by a simple, graphical test. BMJ 1997, 315:629-634.

44. Wang L, Teng Z, Cai S, Wang D, Zhao X, Yu K: The association between the PPAR?2 Pro12Ala polymorphism and nephropathy susceptibility in type 2 diabetes: a meta-analysis based on 9,176 subjects. Diagn Pathol 2013, 8:118.

45. Yu L, Chen J: Association of MHTFR Ala222Val (rs1801133) polymorphism and breast cancer susceptibility: An update meta-analysis based on 51 research studies. Diagn Pathol 2012, 7:171.

doi:10.1186/1746-1596-9-18

Cite this article as: Cheng et al:: RAD51 Gene 135G/C polymorphism and the risk of four types of common cancers: a meta-analysis. Diagnostic Pathology 2014 9:18. 